\title{
Sports Massage Therapy Towards Pre-Competition Anxiety Among Malaysian High Performance Tennis Players
}

\author{
Wan Ahmad Munsif Wan $\mathrm{Pa}^{1^{*}}$, Norlena Salamuddin ${ }^{1}$, Noraziah Mohamad Zin ${ }^{2}$, \\ Denise Koh Choon Lian ${ }^{1}$
}

${ }^{I}$ Faculty of Education, Universiti Kebangsaan Malaysia, 43600 Bangi, Selangor, Malaysia

${ }^{2}$ Faculty of Health Sciences, Universiti Kebangsaan Malaysia, 50300 Kuala Lumpur, Malaysia

*Corresponding author.Email: munsif@ukm.edu.my

\begin{abstract}
The purpose of this study is to discussed about the initial idea of the research regarding pre-competition anxiety, factors of anxiety, scientific impact of SM towards pre-competition anxiety, findings of previous literature, theory and model related to pre-competition anxiety. The idea of coping with pre-competition anxiety is to go through SM therapy. This study will be focusing towards Malaysian high performance tennis athletes. Recently Malaysian high performance tennis players show inconsistent performance that lead into argument of the Malaysian tennis future. The model of Four-Stage Stress Process Model by McGrath (1970), describes the characteristics of the athletes. Multidimensional Theory of Anxiety by Burton (1988), state that there are three components in anxiety which is cognitive anxiety, self-confident and somatic anxiety. All respondent's pre-competition anxiety level will be measure by using Competitive State Anxiety Inventory -2 (CSAI-2) and Enzyme-Linked Immunosorbent Assay (ELISA) Kit. The data obtained will be analyzed using Statistical Packages for the Social Sciences (SPSS) version 23.0 descriptively which involves mean, standard deviation, frequency, percentage and others. SM technique is adapted from Tim Paine (2015). Indeed, the expectation outcome through this concept paper, each sports enthusiast, coach and athlete will have another therapeutic method that can reduce pre-competition anxiety among Malaysian high performance tennis player.
\end{abstract}

Keywords: Sports massage, pre-competition anxiety, tennis, Malaysia

\section{INTRODUCTION}

Moving in this millennium century, there are many psychological methods that athletes can use to achieve success in sports such as motivation, self-confidence, intensity, focus, emotion, goal setting, imagery, routine, coach-athlete relationship and team cohesion (Jim Taylor and Gregory Wilson, 2005.) Moreover, if the athlete has a good internal locus of control and a good expectation of performance will be able to master the relaxation technique (Lehrer and Woolfork 1993). Norlena Salamuddin, Mohd Taib Harun and Sanaa Ali Ahmed Al-Rashed (2014) explained that performing aerobics and strength training exercise can increase selfesteem among university students. Obviously here shows, physical activity or sports can give a positive impact in one's psychological aspect. With optimum relaxation, an athlete is able to produce better coordination, physical and mental recovery, helping to improve sleep or rest quality and improve performance (Vincent A. Parnabas 2014).

This concept paper will unleash the new idea of reducing the pre-competition anxiety among Malaysian high performance tennis player. Previous researchers state that there is positive impact through Sports Massage (SM) therapy towards pre-competition anxiety. Indeed, through this construction of new idea will contribute to the body of knowledge especially to sports psychology and performance.

According to McGrath (1970), stress was identified as unbalanced requirement (physical and psychology) and capability of stimulus under fail condition that will happen and maybe give a critical impact to a person. There is four phase related to the Four-Stage Stress Process Model (McGrath, 1970), phase 1: Environmental Demand, phase 2: Individual's Perception Towards Environmental Demand, phase 3: Stress Response, and phase 4: Behavioral Consequences. 
This model is suitable for the characteristic of the respondent in this study. Figure 1.0 explained details of the model:

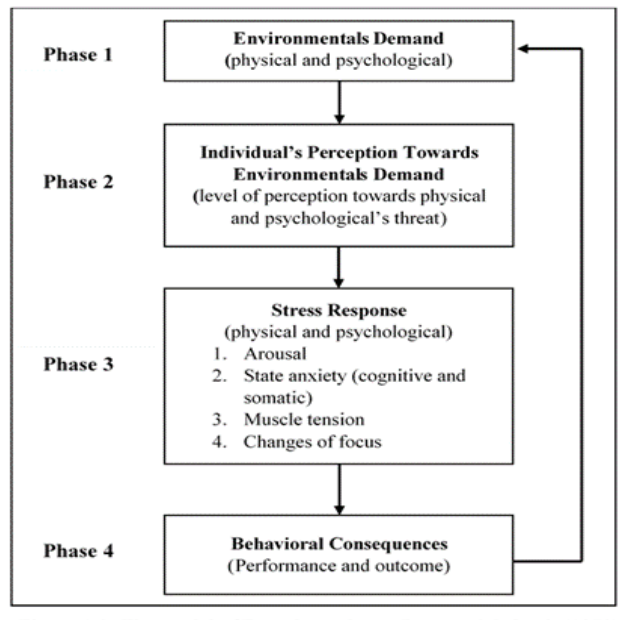

Figure 1.0: The model of Four-Stage Stress Process. McGrath (1970).

Some theories exist about the effects of anxiety on performance, and although there is an interaction effect between the amount of anxiety needed to perform a particular task to the maximum, all theories seem to agree that maximum performance is reduced by too much anxiety (Amasiatu, Athan. N. and Uko, Ime Sampson. 2013). Multidimensional Theory of Anxiety had been founded by Burton in year 1988. This theory expends from the idea of Inverted U hypothesis theory (cognitive and physiological factor). Multidimensional Theory of Anxiety already been used to produce several inventory to measure the character of multidimensional anxiety of state and trait.

Multidimensional anxiety's aspect concluded into three widely concept that is cognitive anxiety, selfconfidence and somatic anxiety. Cognitive anxiety is a mental component that caused by fear towards negative self-measurement and a threat to self's dignity. Selfconfidence is the relations between perception of confidence and outcome of individual's performance. Somatic anxiety is related to physiological aspect for environment anxiety that link directly towards physiological arousal (Martens et al. 1990). Response from physiological aspect such as increase of heart rate, increase rate of breathing, palm of hand become sweat, uncomfortable feeling at stomach and muscle tension. Thus, Multidimensional Theory of Anxiety will be the fundamental theory in this study in order to determine the pre-competition anxiety among Malaysian high performance tennis players.

According to Nelfianty et al. (2017), there is two important factor that affecting individual's anxiety. First factor is situation, divide into two categories which is the importance of competition and inconsistent outcome. The importance of competition defined as, the more important a match becomes, the higher the anxiety faced by the athletes. The level of anxiety seems higher when comes to final round compare to first round of the competition. Meanwhile, the explanations of inconsistent outcome are when the session (selection of the athletes), the level of anxiety is higher for the athletes that is uncertain prior to the selection session compare to the athletes that is already confirmed to be part of the competition or team. For example, selection of new members for the national football team or selection for new national badminton player.

Second factor that lead to anxiety is the individual factor. This factor also consists of two sub-components which is self-efficacy and apprehensive of physical structure. Self-efficacy refers to the athletes who less trust on themselves will lead to greater anxiety to learn skills compare to athletes that have a greater selfconfidence. Apprehensive of physical structure refers to, athletes that worry about their physical structure or appearance will always face with anxiety during competition because they thinking about others perception of their physical looks (Nelfianty et al. 2017).

Even though, Jason Brummit (2008) state that Sports Massage (SM) always performed by physical therapist and famous among athletes and coaches, but the effectiveness is still doubted, specifically on physical and mental aspect. Meanwhile, the statement is differing from Mohamad Nizam and Intan Nur Marliana (2016). One of the best tools that assist the athletes to maintain their physical at the best condition is through SM therapy, compare to conventional warmup and cooling down after high intensity training and prepare for the next training. Moreover, there are several researchers that implement SM therapy as their instrument in the study such as Leivadi S, Hernandez-Reif $M$ and Field T (1999), Micklewright D, Griffin M, Gladwell V, Beneke R. (2005), Seyed Mohammad Zadkhosh, Ehsan Ariaee, Ahmad Ebrahimi Atri, Amir Rashidlamir, Abolfazl Saadatyar (2015).

Kendler et al. (2002) state that, studies show that people with a family history of anxiety have increased their risk of developing it. They have a greater chance of experiencing anxiety disorders that cause ongoing anxiety. Douglas et al (2006) explained that the main sources of pre-competitive anxiety include: fear of failure, over thinking about what people are saying about performance, and lack of confidence. However, they conclude that pre-competitive anxiety depends on factors such as: level of skill, experience and level of general enjoyment of daily activities.

Alison (2006) in Amasiatu, Athan. N. and Uko, Ime Sampson (2013) underlie pre-competitive anxiety as:

a. Physical complaint: Digestive disturbances, shaking and yawning.

b. Fear of failure: Losing, choking, and living up to expectation and making mistake. 
c. Feeling of inadequacy: Poor conditioning, unpreparedness, low skill/ability and feeling that something is wrong.

d. Loss of control: Bad luck, poor officiating and indecent weather.

e. Guilt: Concern about hurting an opponent and cheating.

The scientific impacts of SM therapy are:

a. Recovery: SM was the best method on recovery process after a hectic training or competition (Mohamad Nizam Mohamed Shapie and Intan Nur Marliana Khiri. 2016).

b. Performance: according to Mohamad Nizam Mohamed Shapie and Intan Nur Marliana Khiri (2016), SM had shown a significant difference regarding speed of kicking in taekwando after the SM therapy compare to static stretching method in pre-competition phase. Thus, the researcher state that SM therapy on pre-competition phase, specifically before training, is an effective way and should be implemented in the athlete's training program.

c. Psychology: According to Moraska (2005), the significant impact of the SM therapy is to reduce the level of anxiety among athletes before the real competition. The implementation of SM therapy before competition is the best strategy to reduce the pre-competition anxiety (Cassar MP. 2004). Ever since, massage therapy had been used as a relaxation tool and to improve individual's mood (Galloway S, Watt J, Sharp C. 2004; Weerapong et al. 2005).

d. Physiology: Arabaci (2008) had found that SM has a specific technique to manipulate the muscle fibre arrangement, increase the blood flow in vena and to reduce the lactic acid. Meanwhile, in term of stress hormone (cortisol hormone) level/response, specifically in individual's sports, can be reduced by SM therapy (Jamilah Ahmad Radzi, Sarina Md Yusof and Abdul Aziz Zakaria 2013).

\section{Research Background}

Main problem need to be study by the researcher is about the level of anxiety among athletes. According to Vellapandian (2016), Malaysian national professional's athlete such as Datuk Lee Chong Wei, Datuk Nicole David and Azizulhasni Awang cannot avoid dealing with anxiety before jump into competition. Pressure was increased due to the importance of the competition they are dealing with (Nelfianty et al. 2017). When the anxiety before competition is on demand, this situation will lead to poor performance and fail to perform at their best in the competition (Christian Lee Way, 2015). Pa, Salamuddin, Zin, and Bakar (2019), state that this may be due to lack of emphasis on psychosocial aspects and health promotion. Athletes often have anxiety issues before the game. According to empirical findings from
Omar-Fauzee et al. (2014), there is a significance difference between Indonesia's athlete and Malaysia's athlete for component: facing challenge, focus, mental preparation, goal orientation, performing under pressure and free from worry. Athlete from Indonesia score high only on free from worry's component, compared to athlete from Malaysia that score high on the other component. Thus, this finding showed that athletes from Indonesia do not worry about their performance and do not care about others perception regarding their performance. This sign clearly shows that Malaysian athletes need some solution to overcome their psychological issues to perform at their best.

When an athlete is in a state of anxiety, their ability to perform movements will be impaired and not at their optimum level, and will strive to mimic any other athlete's motor skills or movements during competition (Mullen \& Hardy, 2000). In tennis, double faults should be minimized. This is particularly important in critical match situations (Knisel, 2003) where the success rate of second-serve can be the difference between winning and losing (Djurovic, Lozovina, and Pavicic, 2009). Based on the result of the Malaysian men's tennis player at the 2017 Sea Games Championship, the national players failed to contribute any medal (Kuala Lumpur Sea Games, 2017). Moreover, according to Malaysian national tennis player, Jawairiah Nordin (Malay Mail. 2018), state that the achievement of back-up players was far behind when compared to senior players. Indeed, this is the second reason why Malaysian tennis needs a new approach in the psychological aspect, specifically among high performance tennis players that have a clear mission in the competition phase is to win in every match.

Jason Brummit (2008) state that even though Sports Massage (SM) always performed by physical therapist and famous among athletes and coaches, but the effectiveness is still doubted, specifically on physical and mental aspect. The issues came when the duration and the technique had been applied by masseur and the researcher is different and inconsistent. So, the final problem is regarding the implementation on the SM's technique. Researcher have found another reason to study about the effectiveness of SM therapy towards precompetition anxiety and one of the contribution to mental preparation for the Malaysian high performance tennis player.

Sports Massage Intervention

This intervention will be implemented during precompetition phase, three times a week for three-week duration. In total, the respondents will go through nine session of SM intervention. According to Tim Paine (2015) there are four techniques is sports massage that is effleurage, pettrisage, frictions and tapotament.

$$
\text { Effleurage }
$$

This technique's name was abstracted from France's word called eflleurer which means 'to skim'. Effleurage 
is a gliding technique or long stroke by using hand or palm over the skin at the beginning and end of. This stroking may be used with varying pressure and speed according to purpose and stage of the massage. Effleurage includes light stroking, firm stroking and deep stroking.

This is the first technique that will apply to the targeted muscle by using area of palm of the hand and fingers. Pressure is maintained throughout the stroke and the direction of the stroke is always towards heart to encourage venous return. The overall movement is from proximal to distal. A general rule to follow with all techniques is 'the greater the pressure, the slower the pace'. The aims of effleurage are to:

a. introduce touch to the person,

b. put the person at ease,

c. warm the superficial tissues,

d. relax the muscles,

e. allow the therapist to palpate and sense the condition of the tissue,

f. stimulate peripheral nerves,

g. increase lymph and blood flow,

h. aid the removal of waste products,

i. stretch tissues,

j. relax a person before and end of the massage.

\section{Petrissage}

Petrissage comes from French word, petrir, which means 'to knead'. The fundamental of this movement is to compress and the release the soft tissue, using either direct pressure or with picking up and squeezing the skin and muscle.

This technique is generally applied for deeper effect on soft tissue than effleurage, and includes kneading, squeezing, picking up, shaking (wringing and rolling). Petrissage also applying pressure directed towards the heart to promote venous return. The surface of therapist's hands often remains in almost static contact with the person's skin while moving it over the underlying muscle. The stroke and overall direction are towards heart. At the beginning of this stroke, therapist first applies generally shorter strokes towards heart, but after one or more strokes deliberately slides the hands distally before commencing the technique again. The objective is to 'push' blood out of an area of soft tissue by applying pressure, then releasing the pressure before repeating the maneuver distally to force fresh blood and nutrients into the area just 'vacated'. The aims of petrissage are to:

a. increase mobility between tissue interfaces,

b. stretch muscle fibre,

c. aid to interchange of tissue fluids,

d. increase venous and lymphatic return,

e. relax muscles,

f. aid the removal of waste products.
This technique is tiny forceful movement or pressure will directly apply back and forth over isolated areas using pads of the fingers or thumbs by using considerable pressure compared to effleurage and petrissage technique. This technique is also known as 'cross-fibre' friction.

When apply this technique for the purpose if separating muscle fibre and breaking down scar tissue, the person must be warned that these procedures might be painful or at the very little uncomfortable situation, even though the pain will subside after a short while. The aims of frictions are to:

a. separate adhesions between fibres,

b. break down scar tissues,

c. restore elasticity,

d. stimulate the healing process,

e. realign new scar tissue.

\section{Tapotament}

This technique's name was derived from France's word called tapoter, defined as percussion. This technique specifically consists two type of tapotament that is hacking and cupping. Hacking is in which both hands alternately strike the skin with the lateral borders of the fifth finger of each hand. As the fingers close together during striking the skin, a sound is made. This technique is for preparing the muscle for exercise and hence being an option for pre-competition massage.

Cupping involves making an airtight concave shape with the hand, and then strikes the surface, the air caught underneath is compressed, creating a vibration that penetrates the tissues, characteristically creates a vacuum as the hands are pulled away.

The research objectives are to:

a. identify the level of pre-competition anxiety among Malaysian high performance tennis players.

b. identify the difference of pre-competition anxiety among Malaysian high performance tennis players before and after the Sports Massage intervention in term of gender.

c. suggest one model of SM for pre-competition phase. The research questions are:

a. What is the level of pre-competition anxiety among Malaysian high performance tennis players?

b. What is the difference of pre-competition anxiety among Malaysian high performance tennis players before and after the Sports Massage intervention in term of gender?

\section{METHOD}

The design of this study is experimental quantitative study. This method is suitable for this study because researcher will apply an intervention of sports massage to see the impact for pre and post outcome of sports massage towards pre-competition condition by given the questionnaire to the respondents as possible (Robert, 
Spink \& Pemberton, 1999) to obtain information about the level of pre-competition anxiety.

Respondents in this study will be selected through purposive sampling. The population of this study is the athletes who are Malaysian high performance tennis players that train regularly for the national and international competition. All of these athletes considered as high performance because they have the same mission is to win in every match (Aras Khamis. 2017). The athletes will be trained at the National Tennis Center, Kuala Lumpur under supervision of the Lawn Tennis Association of Malaysia.

The instruments of this research are:

a. Self-reported psychometric questionnaire: The Competitive State Anxiety Inventory - 2 (CSAI-2) produced by (Martens, Burton, Vealey, Bump, \& Smith, 1990) will be used in this study. It consists of 27 questions to be answer by the respondents. This instrument assesses cognitive anxiety, somatic anxiety and self-confidence in athlete performance.

b. Cortisol hormone test: Enzyme-Linked Immunosorbent Assay (ELISA) Kit is an in vitro assay for the quantitative measurement of Cortisol in saliva. Cortisol is a steroid hormone released from the adrenal cortex. Thus, individual stress response can be determining throughout cortisol hormone.

The data obtained will be analyzed using Statistical Packages for the Social Sciences (SPSS) version 23.0 descriptively which involves mean, standard deviation, frequency, percentage and others. Dependent T-Test will be used to determine the difference of pre-competition anxiety among high performance tennis players before and after the Sports Massage intervention in term of gender.

Through this concept paper, researcher is expecting that there are several positive outcomes which is can identify the level of pre-competition anxiety before and after the intervention among the Malaysian high performance tennis players. Athletes also can reduce their pre-competition anxiety and positively can increase their performance during competition. Moreover, this idea can increase the awareness sports massage (SM) and its importance to overcome the pre-competition anxiety, not only as recovery tool.

Through this concept paper, the readers are expected to gain knowledge about the purpose and the technique of the SM. Indeed, it is also hoped that this study will explore aspects which should be emphasized for the masseur or massage therapist to deliver the right technique or method to their athletes.

\section{CONCLUSION}

In enhancing the level of sports performance based on mental preparation prior to the actual match, existing knowledge, tactical and technical skills as well as effective training programs are important factors in producing high performance tennis players in Malaysia. As a result, new ideas, new technologies and new methods of training have been developed to meet the changing demands of the times.

Researchers find it is very important to conduct research on the mental and physical preparation of tennis players to perform at international or national championships. SM therapy can be use as psychology aid along with other psychological skills such as selftalk, imagery and mental rehearsal to overcome anxiety problem among athletes. Hopefully this kind of study can be added in the module of Malaysian high performance tennis player's training programs to achieve peak performance and also encourage them to increase their mental, physical and skill performance before, during and after competition/training.

Therefore, an empirical study should be conducted to prove that SM therapy can have a holistic impact on prematch psychology among high-performance tennis players. In particular, the results of the SM therapy are expected to provide significant benefits in reducing the problem of pre-competition anxiety among highperformance tennis players in Malaysia.

\section{REFERENCES}

Alexandros Mavvidis, Aggelos Stamboulis, Vassilis Dimitriou, Aspasia Giampanidoy 2010. Differences in Forehand and Backhand Performance in Young Tennis Players. Studies in Physical Culture and Tourism Vol. 17, No. 4, 2010

Alison, C. (2006). Anxiety Disorder and Learning. Hisdale. N. J.: Erlbaum.

Amasiatu, Athan. N. and Uko, Ime Sampson. 2013. Coping with Pre-Competitive Anxiety in Sports Competition. European Journal of Natural and Applied Sciences. Vol. 1, Issue 1.

Arabaci R. 2008. Acute effects of pre-event lower limb massage on explosive and high speed motor capacities and flexibility. Journal of Sports Science and Medicine (2008) 7, 549-555.

Aras Khamis. 2017. Model Pembangunan Jangka Panjang Atlet (Field Hockey Canada). Kesan Small Sided Gamme (SSG) Terhadap Kemampuan Fizikal dan Kognitif, Kemahiran Asas dan Aspek Psikologi Pemain-pemain Hoki.

Arroyo-Morales M, Fernández-Lao, C, Ariza-García A, Toro-Velasco, C, Winters M, Díaz-Rodríguez L., Cantarero-Villanueva I, Huijbregts P., \& Fernández-De-las-Peñas $\quad$ C. 2011. Psychophysiological effects of preperformance massage before isokinetic exercise. J Strength Cond Res, 25(2), 481-488.

Burton, D. 1988. Multidimensional Anxiety Theory. Do Anxious Swimmers Swim Slower? Re-examining the Elusive Anxiety-Performance Relationship. 
Journal of Sport and Exercise Psychology, 10, 45-61.

Cassar MP. 2004. Handbook of Clinical Massage: A Clinical Guide for Students and Practitioners. 2nd ed. Edinburgh: Churchill Livingstone.

Christian Lee Way. 2015. Performance Enhancement and Precompetitive Anxiety Management among USAG Junior Olympic Gymnasts. Walden Dissertations and Doctoral Studies.

Chua Yan Piaw. 2011. Kaedah Penyelidikan. Buku 1; Edisi Kedua. McGraw Hill Malaysia Sdn. Bhd.

Connor Outram. 2014. Multidimensional Theory of Anxiety: diagram. The Perceived Impact of Competitive State Anxiety Over Performance; A Study Determining the Differences Between Individual and Team Sports Athletes. Dissertation. Cardiff School of Sport. Cardiff Metropolitan University.

Djurovic, N., Lozovina, V., and Pavicic, L. (2009). Evaluation of tennis match data-New acquisition model. Journal of Human Kinetics, 21, 15-21. doi:10.2478/v10078-09-0002-9.

Douglas, A., Louis, A., Alison, C., Edward, J. (2006). Psychology (Seven edition). Houghton Mifflin Company, Boston N. Y.

Galloway S, Watt J, Sharp C. 2004. Galloway S, Watt J, Sharp C. Massage provision by physiotherapists at major athletic events between 1987 and 1998. Br J Sport Med. 2004; 38: 235-237.

Jamilah Ahmad Radzi, Sarina Md Yusof dan Abdul Aziz Zakaria. 2013. Pre-Competition Anxiety Levels in Individual and Team Sports Athletes. Proceeding of the International Conference on Social Science Research, ICSSR 2013 (e-ISBN 978-967-11768-1-8).

Jason Brummit. 2008. The Role of Massage in Sports Performance and Rehabilitation: Current Evidence and Future Direction. North American Journal of Sports Physical Therapy. Volume 3, Number 1.

Jim Taylor \& Gregory Wilson. 2005. Applying Sport Psychology: Four Perspectives. University of Evansville. Human kinetics.

Kendler, K., Jacobson, S., Meryer, C. (2002). Sex differences in genetic and environmental risk factors for irrational fear and phobias. Psychological Medicine. 32, 209-217.

Knisel, E. 2003. Kritische Spielsituationen im Tennis und deren Bewaltigung [Critical match situations in tennis and its coping]. Schorndorf, Germany: Verlag Karl Hofmann.

Kuala Lumpur Sea Games. 2017. Pungutan pingat. https://www.kualalumpur2017.com.my/BM/seag ames-country.cshtml [30 Mei 2018]

Lehrer, Paul M. and Woolfolk, Robert L. (Eds.). 1993. Principles and Practice of Stress Management (2nd ed.). American Journal of Clinical Hypnosis 37(3):621. New York: Guilford Press.

Leivadi S, Hernandez-Reif M \& Field T. 1999. Massage therapy and relaxation effects on university dance students. J Dance Med Sci. 1999; 3:108-112.

Malay Mail. 2018. Malaysian tennis players lack exposure, says Jawairiah Noordin. https://www.malaymail.com/news/sports/2018/07 /29/malaysian-tennis-players-lack-exposure-saysjawairiah-noordin/1657162 [24 Februari 2019]

Martens, R., Burton, D., Vealey, R.S., Bump, L.A., \& Smith, D.E. 1990. Development and validation of the Competitive State Anxiety Inventory-2 (CSAI-2). In R. Martens, R.S. Vealey, \& D. Burton (Eds.), Competitive anxiety in sport (pp. 193-208). Champaign, IL: Human Kinetics.

McGrath, J. E. 1970. A conceptual formulation for research on stress. In J. E. McGrath (Ed.), Social and psychological factors in stress (pp.10-21). New York: Holt, Rinehart, \& Winston.

Micklewright D, Griffin M, Gladwell V, Beneke R. 2005. Mood state response to massage and subsequent exercise performance. The Sport Psychologist. 2005; 19:234-250.

Mohamad Nizam and Intan Nur Marliana. 2016. The Effect between Static Stretching and Pre-Event Massage on Kicking Speed Score among Taekwondo Athletes.

Moraska A. 2005. Sports massage: a comprehensive review. Journal of Sports Medicine and Physical Fitness. 2005; 45(3): 370.

Moyer C.A., Rounds J. and Hannum J.W. 2004. A metaanalysis of massage therapy research. PubMed Central Articles 30 (1): 3-18.

Mullen, R., and Hardy, L. 2000. State Anxiety and Motor Performance: Testing the Conscious Processing Hypothesis. Journal of Sports Sciences, 18, 785-799. http://dx.doi.org/10.1080/02640410041984

Nelfianty binti Mohd Rasyid, Jeffrey Low Fook Lee, Normah binti Jusoh, Ruaibah Yazani binti Tengah. 2017. Faktor-faktor Kebimbangan: Kebimbangan dan Kemahiran Psikologi Sukan: Bidang 6. Buku Teks Sains Sukan, Tingkatan 5. Aras Mega (m) Sdn. Bhd.

Nelfianty binti Mohd Rasyid, Jeffrey Low Fook Lee, Normah binti Jusoh, Ruaibah Yazani binti Tengah. 2017. Faktor-faktor Kebimbangan: Kebimbangan dan Kemahiran Psikologi Sukan: Bidang 6. Buku Teks Sains Sukan, Tingkatan 5. Aras Mega (m) Sdn. Bhd

Norlena Salamuddin, Mohd Taib Harun and Sanaa Ali Ahmed Al-Rashed. 2014. The Effects of Selected Aerobic Exercise Modalities on Self Esteem among Female Students. Asian Social Science 10(5): 141-145. 
Omar-Fauzee, Yahya Don, Nina Susterna, Yudha M. Saputra, Sofyan Hanif, Nagoor Meera Abdullah \& Mohd Izwan Shahril. 2014. Examining The Indonesia and Malaysia Student Athletes Coping Strategy in Sports. European Scientific Journal Special Edition Vol. 2 ISSN: $1857-7881$.

Pa, W. A. M. W., Salamuddin, N., Zin, N. M., \& Bakar, A. Y. A. 2019. Service Quality among Sports and Fitness Practitioners in Malaysia: A Case Study. International Journal of Academic Research in Business and Social Sciences, 9(7), 273284.Samuel Blechman. 2010. Massage for Athletes. AMTA National Convention.

Robert, G. C., Spink, K. S., \& Pemberton, C. L. (1999). Learning Experiences in Sport Psychology. A practical guide to help students understand the major concepts in sport psychology. UnitedStates of America. Champaign, IL: Human Kinetics.

Samuel Blechman. 2010. Massage for Athletes. AMTA National Convention.

Seyed Mohammad Zadkhosh, Ehsan Ariaee, Ahmad Ebrahimi Atri, Amir Rashidlamir, Abolfazl Saadatyar. 2015. The Effect of Massage Therapy On Depression, Anxiety and Stress in Adolescent Wrestlers. International Journal of Sport Studies. Vol., 5 (3), 321-327.

Tim Paine. 2015. The Complete Guide to Sports Massage. ISBN: 9781472912329.

Vellapandian Ponnusamy. 2016. Kekuatan Mental Nadi Atlet. Harian Metro. Sports performance division. National Sports Institute of Malaysia.

Vincent A. Parnabas, Yahaya Mahamood, Julinamary Parnabas and Nagoor Meera Abdullah. 2014. The relationship between relaxation techniques and sport performance. Universal Journal of Psychology 2(3): $108-112$.

Weerapong P, Hume PA, and Kolt GS. 2005. The mechanisms of massage and effects on performance, muscle recovery, and injury prevention. Sports Med. 2005; 35:235-256. Yang, J., Peek-Asa, C., Corlette, J. D., Cheng, G., Foster D. T., \& Albright, J. 2007. Prevalence of and risk factors associated with symptoms of depression in competitive collegiate student athletes. Clinical Journal of Sport Medicine, 17(6), 481-487.

Wiebe, R. 1980. Koordinationstest im Sportspiel Tennis. Deutsche Sporthochschule Koeln: Diplomarbeit. 